\title{
UV treatment efficiency for E. coli in storm water containing different size fractions of suspended solids
}

\author{
S. McElmurry ${ }^{1} \&$ N. Khalaf $^{2}$ \\ ${ }^{1}$ Department of Civil \& Environmental Engineering, \\ Wayne State University, USA \\ ${ }^{2}$ Detroit Contracting, Inc., USA
}

\begin{abstract}
Ultraviolet (UV) treatment of water is known to be an effective means for reducing bacterial concentrations. While previous research has typically focused on UV treatment efficiency for disinfection of drinking water, the utility of this technology in treating more turbid samples is less clear. This study investigates the use of UV treatment for the disinfection of storm water from combined sewer overflow (CSO) events and specifically focuses on how suspended solids influence treatment efficiency for Escherichia coli. Storm water containing different size fractions of suspended solids was exposed to UV treatments and the rate of disinfection was determined. After approximately 3 orders of magnitude reductions in E. coli survival, significant tailing in the rate of disinfection was observed for unfiltered storm water and storm water containing particles less than $20 \mu \mathrm{m}$. A particle associated bacteria (PAB) model which directly utilizes the concentration of suspended solids to estimate the effect of shielding is proposed and evaluated as well as a biphasic model, with two first-order rate constants. Experimental results confirm that suspended particles are important and need to be accounted for when determining UV treatment efficiency of CSO storm water. However, tailing observed may not be accurately described by current models and particle size suggests a mechanism other than shielding is responsible for tailing.
\end{abstract}

Keywords: ultraviolet treatment, storm water, E. coli, suspended solids. 


\section{Introduction}

Ultraviolet (UV) treatment has been used effectively to disinfect drinking water [1]; however its utility to disinfect storm water has not been fully evaluated. The primary reason UV treatment has not been employed for storm water treatment is the orders of magnitude of larger amounts of suspended solids, in addition to dramatically different solution chemistry, observed in storm water when compared to drinking water sources [2]. Additionally, unlike typical sources of drinking water, the composition of storm water is extremely dynamic, particularly during combined sewer overflow (CSO) events. The rapidly changing concentrations of suspended particles, measured as total suspended solids (TSS), observed in storm water are known to interfere with UV transmission and thus greatly decrease UV treatment efficiency [3-5]. If systems were to be designed appropriately to remove particles it may be possible to utilize UV treatment for storm water. Unfortunately, due to the inability to accurately predict treatment efficiency as a function of TSS, it is not currently possible to design or evaluate UV treatment systems for storm water. Therefore, determining how particles influence UV treatment is critical for evaluating the utility of UV disinfection for CSO water.

Ultraviolet disinfection differs from other typical forms of disinfection as it does not require the addition chemicals and does not leave a residual [6]. The mechanism for UV disinfection transfers electromagnetic energy, typically from a mercury arc lamp, to the genetic material (DNA and RNA) present in pathogens (bacteria, viruses, etc.). The "germicidal range" of the UV spectrum, or the portion of the spectrum which is effective in UV disinfection, is 200 $300 \mathrm{~nm}$ [7]. Because UV radiation impacts the genetic material, an effective dose of UV radiation renders the organism no longer capable of reproducing, despite cell membranes and enzymes remaining relatively intact [8].

While the response of organisms to UV exposure varies, Escherichia coli serves as suitable model bacteria to study UV disinfection since it is commonly used as an indicator organism of wastewater contamination [9]. E. coli is a gramnegative rod shaped bacteria approximately $1.8 \mu \mathrm{m}$ long and $0.8 \mu \mathrm{m}$ in diameter [10]. First-order decay has been observed for the initial disinfection of E. coli in aqueous samples (e.g. [11]). The typical UV dose required to effectively kill $90 \%$ and $99 \%$ of E. coli is reported to be 3.0 to $6.6 \mathrm{~mW} \mathrm{~cm}^{2}$, respectively [12]. The initial rate constant of $0.055 \mathrm{~cm}^{2} \mathrm{~mW}^{1} \mathrm{sec}^{1}$ for E. coli disinfection has been reported for wastewater samples [11].

Unfortunately, the use of previously reported rate constants and direct comparison of UV treatment efficiency is difficult due to a variety of experimental designs and incomplete documentation [13]. As a result, standardized designs for UV irradiation chambers (collimated beam) have been suggested to increase the confidence in data generated during experiments. Regardless of the difficulties in evaluating previous studies, research has demonstrated that suspended solids decrease the rate of UV disinfection with particles larger than $20 \mu \mathrm{m}$ being more effective in shielding bacteria than smaller 
particles [14]. As a result of particles being present in solution, tailing is commonly observed when UV dose exceeds $30 \mathrm{~mW}$ sec $\mathrm{cm}^{2}$. This tailing is commonly assumed to be the result of particles inhibiting UV exposure [15]. To address the tailing observed Emerick et al. [16] is one of many that has developed a model to describe the increase in bacterial survival observed during tailing that is assumed to be from particle associated coli form bacteria? When models such as the one proposed by Emerick et al. [16] are combined with existing knowledge regarding suspended solids in storm water, it may be possible to describe the observed tailing as a function of TSS, providing for a quick and effective means of evaluating UV treatment efficiency of CSO water.

The purpose of this paper is to evaluate the effect of suspended solids on the treatment efficiency of a common indicator organism, E. coli, in CSO water. Two models, a modified version of the model proposed by Emerick et al. [16] and a biphasic model, were evaluated to determine their ability to describe the tailing effect observed during UV treatment. Three types of CSO samples were tested: (1) unfiltered, (2) $<20 \mu \mathrm{m}$ fraction and (3) $<5 \mu \mathrm{m}$ fraction. Samples were exposed to increasing doses of UV radiation and the model fit was evaluated. Results support previous studies which suggest particle size is an important factor, not just particle number, in determining UV treatment efficiency.

\section{Methods}

\subsection{Sample collection}

Samples of CSO water were collected during 3 storm events from the Saint Aubin CSO facility in Detroit, Michigan, USA. The samples were collected on September 22, 23 and October 10, 2010 within 8hrs of initial rainfall. The sewer system feeding the St. Aubin facility is one of the largest in the United States resulting in considerable mixing of storm water runoff and sewage prior to flows reaching the facilities. All samples were collected well after the peak flow during the falling limb of the hydrograph. Due to the large flows observed at the facility and the time samples were collected, the initial concentration of total suspended solids in samples prior to filtration were low $\left(\sim 30 \mathrm{mg} \mathrm{L}^{1}\right)$.

\subsection{Sample treatments}

After collection, samples were gently stirred until they reached room temperature $\left(\sim 20^{\circ} \mathrm{C}\right)$ when they were filtered by a $20 \mu \mathrm{m}$ and $5 \mu \mathrm{m}$ filter. The three sample types evaluated were an unfiltered sample, a $<20 \mu \mathrm{m}$ fraction and a $<5 \mu \mathrm{m}$ fraction. After preliminary experiments failed to show any bacteria surviving filtration through a $5 \mu \mathrm{m}$ filter when the fractions were tested immediately after filtration, samples were allowed to sit for $24 \mathrm{hrs}$ before UV treatment and bacterial quantification (described later). With the $24 \mathrm{hr}$ recovery period the number of bacteria present in solution was found to be reproducible and it was assumed that this time was essential to allow for bacteria to recover from the physical stress induced by filtering [17]. 
As recommended by Bolton and Linden [13], samples were dosed with UV light in a custom built exposure chamber constructed from untreated pine wood that contained two apertures to achieve a collimated beam of UV light at the sample surface. The chamber utilized three 14in long, low pressure mercury lamps (Atlantic Ultraviolet Corporation; Hauppauge, NY) for irradiation. Low pressure UV lamps emit nearly monochromatic light at $253.7 \mathrm{~nm}$, almost the peak of germicidal effectiveness for E. coli [18]. A germicidal radiometer (Model ILT77, International Light Technologies; Peabody, MA) was used to evaluate the lamp output at the sample surface. The ILT77 has a spectral response range of 214360nm (peaks at $280 \mathrm{~nm}$ ) making it ideal to monitor low pressure mercury lamps. Output from the lamps was measured before and after each sample was exposed to UV light. Typical germicidal light values observed in the collimated beam unit ranged from $0.79 \mathrm{~mW} \mathrm{~cm}$ to $0.83 \mathrm{~mW} \mathrm{~cm}$ at the surface of the sample.

During sample exposure, a magnetic stir bar agitated the samples at a low speed $(\sim 150 \mathrm{rpm})$ using a stir plate. Triplicate samples were exposed to the collimated beam of UV light at room temperature $\left(24^{\circ} \mathrm{C}\right)$ in the chamber for 10 to 240 seconds to achieve the desired dose. For control, three samples containing known quantities of E. coli were prepared and quantified but not exposed to UV irradiation. After irradiation, the aqueous samples were filtered through a $0.45 \mu \mathrm{m}$ membrane filter (Millipore; Billerica, MA). Membrane filters were placed directly onto the surface of freshly prepared $\mathrm{mFC}$ agar medium (EMD Chemicals; Gibbstown, NJ) and incubated at $44.5^{\circ} \mathrm{C}$ for 24 hours after which the number of colonies were quantified [19].

\subsection{Deactivation models}

Two models were used to describe bacterial survival, (1) a common biphasic first-order decay model [20] and (2) a modified version of the model proposed by Emerick et al. [16] for which TSS is used to predict the particle number.

\subsubsection{Biphasic first-order decay}

The rate of decay can be modelled as two first-order rates of decay [20]. A biphasic model describes bacterial decay during both the initial and tail phases with two first-order rate constants which can are based on the following equation:

$$
\frac{\mathrm{dN}}{\mathrm{dt}}=-\mathrm{kD}
$$

where $\mathrm{N}$ is the number of viable bacteria (E. coli), typically measured as colony forming units (CFU) per $100 \mathrm{~mL}$; $\mathrm{t}$ is time (sec); $\mathrm{k}$ is the first-order rate constant $\left(\mathrm{cm}^{2} \mathrm{~mW}^{1} \mathrm{sec}^{1}\right)$ and $\mathrm{D}$ is the dose $\left(\mathrm{mW} \mathrm{sec} \mathrm{cm}^{2}\right)$. The dose can be defined by the following equation:

$$
\mathrm{D}=\mathrm{I} \cdot \mathrm{t}
$$


where D is the dose $\left(\mathrm{mW} \mathrm{sec} \mathrm{cm}^{2}\right)$, I is the UV intensity $\left.(\mathrm{mW} \mathrm{cm})^{2}\right)$ and $\mathrm{t}$ is length of time $(\mathrm{sec})$ the bacteria have been exposed to the UV light of specified intensity. Upon integration and rearrangement, equation (1) can be used to predict the relative concentration of bacteria (i.e. bacterial survival) as a function of time using the following equation:

$$
\mathrm{N}(\mathrm{t})=\mathrm{N}(0) \mathrm{e}^{-\mathrm{kD}}
$$

where $\mathrm{N}(\mathrm{t})$ is the total number bacteria (CFU per $100 \mathrm{~mL})$ measured at time $\mathrm{t}$ $(\mathrm{sec}), \mathrm{N}(0)$ is the total number of dispersed coliform bacteria (CFU per $100 \mathrm{~mL}$ ) at $\mathrm{t}=0 \mathrm{sec}, \mathrm{D}$ is the dose $\left(\mathrm{mW} \mathrm{sec} \mathrm{cm}^{2}\right), \mathrm{k}$ is the rate constant for disinfection of dispersed bacteria $\left(\mathrm{cm}^{2} \mathrm{~mW}^{1} \mathrm{sec}^{1}\right)$, and $\mathrm{N}(0)$ is the total number of bacteria at $\mathrm{t}=0$. As described previously, the initial decay of E. coli (doses less than $\sim 30 \mathrm{~mW} \mathrm{sec} \mathrm{cm}^{2}$ ) can be accurately modeled using a single first-order decay term (e.g. Madge and Jensen [11]). Accurately modeling the survival of bacteria in both the initial and tailing phases can be accomplished by adding a second first-order rate expression (i.e. equation (3)), resulting in a biphasic model described by the following equation:

$$
\mathrm{N}(\mathrm{t})_{\text {total }}=\mathrm{N}(\mathrm{t})_{\text {initial }}+\mathrm{f}_{\text {tail }} \cdot \mathrm{N}(\mathrm{t})_{\text {tail }}
$$

where $\mathrm{N}(\mathrm{t})_{\text {total }}$ is the total number of bacteria (CFU per $\left.100 \mathrm{~mL}\right)$ at time $\mathrm{t}(\mathrm{sec})$, $\mathrm{N}(\mathrm{t})_{\text {initial }}$ is the number of bacteria $(\mathrm{CFU}$ per $100 \mathrm{~mL})$ at time $\mathrm{t}(\mathrm{sec})$ remaining from the initial first-order decay, $\mathrm{f}_{\text {tail }}$ is the fraction of bacteria subject to the slower decay rate observed during tailing and $\mathrm{N}(\mathrm{t})$ tail is the number of bacteria (CFU per $100 \mathrm{~mL}$ ) at time $\mathrm{t}(\mathrm{sec})$ that is found to decay at the rate observed during tailing. To avoid inaccurately estimating the first-order rates of decay, the initial rate of decay was determined for UV doses $0-15 \mathrm{~mW} \mathrm{sec} \mathrm{cm}^{2}$ and the rate of decay during tailing was determined for UV doses $>30 \mathrm{~mW} \mathrm{sec} \mathrm{cm}^{2}$. The fraction of bacteria subjected to the rate of decay observed during tailing (fail) was estimated by the intercept of the trend-line used to determine the tailing first-order decay rate.

\subsubsection{Emerick particle-associated bacteria model}

The deactivation of bacteria, particularly the tailing observed, in a batch system can be predicted using a model that accounts for the particle-associated bacteria (PAB) formulated by Emerick et al. [16]. Similar to the biphasic first-order decay model, the initial rate of bacterial decay must be known, or fitted to observed data, to predict survival. Unlike the biphasic first-order decay model, the initial rate of decay is assumed to be a first-order rate of inactivation during tailing with additional terms to account for shielding due to particles. Again, the initial rate of decay was approximated using the observed survival for UV doses less than $15 \mathrm{~mW} \mathrm{sec} \mathrm{cm}^{2}$. Because this model requires observed data to be fitted, the model is only predictive for bacterial survival during tailing $(>15 \mathrm{~mW}$ sec $\mathrm{cm}^{2}$ ), not over an entire range of UV dose. 
The model proposed by Emerick et al. [16] is described by the following equation:

$$
N(t)=N_{D}(0) e^{-k D}+\frac{N_{P}(0)}{k D}\left(1-e^{-k D}\right)
$$

where $N(t)$ is the total number of measured coli form bacteria at time t, $N D(0)$ is the total number of dispersed coli form bacteria at $\mathrm{D}=0, \mathrm{D}$ is the dose $(\mathrm{mW}$ sec $\left.\mathrm{cm}^{2}\right)$; $\mathrm{k}$ is the rate constant for disinfection of dispersed bacteria, and $\mathrm{NP}(0)$ is the total number of particles containing at least one coli form bacteria at $\mathrm{D}=0$.

The following equation describing the relationship between TSS and the number of particles has been reported by Li et al. [21]:

$$
\log (\mathrm{P})=\frac{\log (\mathrm{TSS})+3.01}{0.9}
$$

where $\mathrm{P}$ is the number of $2-1,000 \mu \mathrm{m}$ particles per milliliter (i.e. particle concentration) and TSS is the total suspended solids $(\mathrm{mg} / \mathrm{L})$. Assuming the number of particles with at least one E. coli bacterium is $12 \%$ of the total number of particles [16], equations (5) and (6) can be combined to provide the following equation describing bacterial survival:

$$
\mathrm{N}(\mathrm{t})=\mathrm{N}_{\mathrm{D}}(0) \mathrm{e}^{-\mathrm{kD}}+\frac{265.232 \cdot \mathrm{TSS}^{1.11}}{\mathrm{kD}}\left(1-\mathrm{e}^{-\mathrm{kD}}\right)
$$

Given the initial rate of decay, the particle-associated bacteria (PAB) model (equation (7)) should predict the tailing observed for a specified concentration of suspended solids.

\subsection{Statistical test}

To assess model fit the Wilcoxon ranked-sign technique was used. The Wilcoxon signed-rank test is a nonparametric test for evaluating data which is not normally distributed [22]. Essentially, the Wilcoxon ranked-sign test is the nonparametric equivalent of the paired t-test.

\section{Results and discussion}

Disinfection efficiency was found to be dependent on particle size (Fig. 1). The biphasic model was found to accurately (within 95\% confidence) predict bacterial survival. As the particle size fraction decreased, the treatment efficiency decreased. The initial rate constant (dose $<15 \mathrm{~mW} \mathrm{sec} \mathrm{cm}^{2}$ ) was found to be $0.201,0.140$ and $0.078 \mathrm{~cm}^{2} \mathrm{~mW}^{1} \mathrm{sec}^{1}$ for the unfiltered ( $\left.\mathrm{r} 2=0.9997\right),<20 \mu \mathrm{m}$ $(\mathrm{r} 2=0.895)$ and $<5 \mu \mathrm{m}(\mathrm{r} 2=0.895)$ samples, respectively. Using the biphasic model, the first-order rate constant observed during tailing (dose $>30 \mathrm{~mW}$ sec $\mathrm{cm}^{2}$ ) was found to be relatively consistent between samples and range from 0.0062 to $0.0105 \mathrm{~cm}^{2} \mathrm{~mW}^{1} \mathrm{sec}^{1}$. The fraction of bacteria subjected to the rate of decay observed during tailing $\left(\mathrm{f}_{\text {tail }}\right)$, identified by the intercept of the regression 
line used to determine the second of the first-order rate constants, was found to be $0.03 \%, 0.06 \%$ and $1.2 \%$ of the bacteria present in the unfiltered sample, $<20 \mu \mathrm{m}$ fraction and $<5 \mu \mathrm{m}$ fraction, respectively.

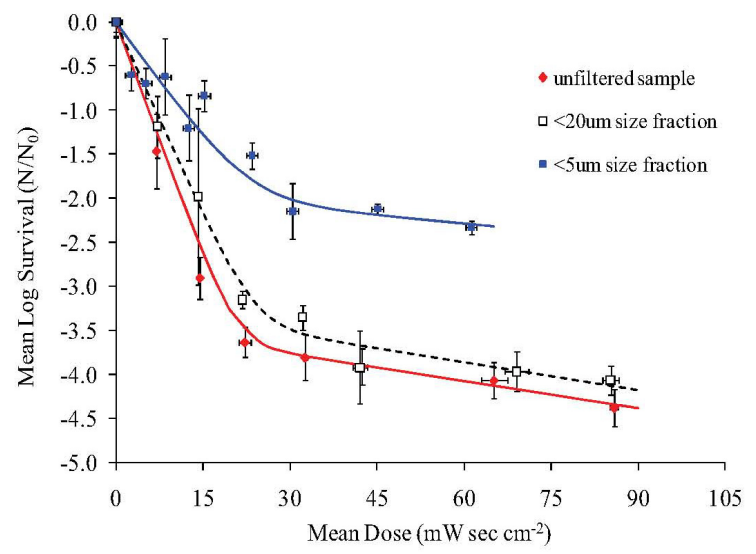

Figure 1: Survival of E. coli versus dose of UV irradiation for CSO water containing different particle size fractions fit with a biphastic firstorder kinetic model.

This "resistant" fraction is within the range described by others (e.g. Hellweger et al. [20]). The reason for the observed "resistant" fraction is a focus of current research. It is also interesting to note that when a UV dose greater than $40 \mathrm{~mW} \mathrm{sec} \mathrm{cm}^{2}$ was applied, the percentage of bacteria that undergo photo reactivation is found to remain relatively constant $(<1 \%)$ [23].

The PAB model was found to approximate the shape of the tailing curve observed in UV disinfection when particles are present (Fig. 2). However, the PAB model was found to generally over predict UV disinfection for solutions containing small diameter particles (Fig. 2(c)) and under estimates UV disinfection when solutions contain larger diameter particles. For the fraction containing particles under $20 \mu \mathrm{m}$ size, the PAB model was found to be statistically different, with $95 \%$ confidence, from the observed results. While the bacterial survival predicted by the PAB model is not statistically different $(>95 \%$ confidence) from the observed bacterial survival for the $<5 \mu \mathrm{m}$ fraction, the model prediction diverges from the biphasic model and the observed survival as the UV dose increases.

While results suggest the $\mathrm{PAB}$ model predicts tailing with reasonable accuracy for unfiltered solutions (Fig. 2(a)), the influence of particle size does not appear to be accurately captured. This is not surprising since particle size is not directly represented in equation (7). Furthermore, the PAB model was based on the assumption that approximately $12 \%$ of the particles $10-80 \mu \mathrm{m}$ in size present in wastewater contained bacteria [16]. While this may accurately predict the fraction of bacteria associated with larger size particles in wastewater, if the 


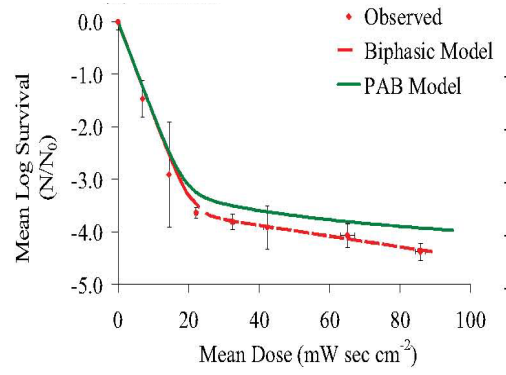

(a)

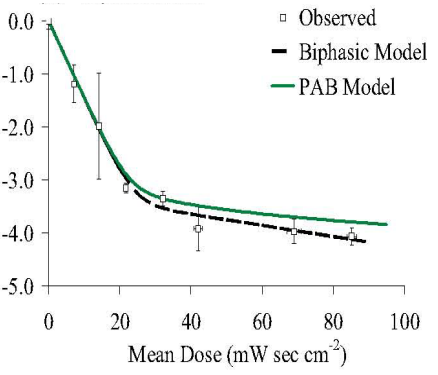

(b)

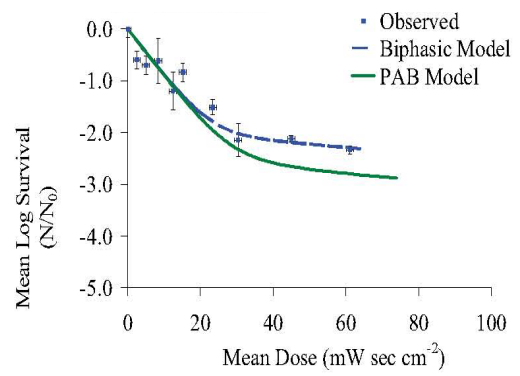

(c)

Figure 2: Model results describing E. coli versus dose of UV irradiation for (a) unfiltered sample, (b) $<20 \mu \mathrm{m}$ fraction and (c) $<5 \mu \mathrm{m}$ fraction of CSO water.

results are accurate it would appear to suggest the fraction of bacteria associated with smaller particles may be greater than $12 \%$. If the number of bacteria associated with particles increased in the PAB model then survival of bacteria would increase and results could approach the observed bacterial survival in the tailing phase. However, there are two problems with assuming there is an increased protective factor associated with smaller particle fractions. First, while it is possible that particles smaller than bacteria could provide shielding from UV treatment (e.g. via coagulation), the small particle size fraction $(<5 \mu \mathrm{m})$ used in this study are not likely to provide significant shielding since this size is close to the size of E. coli [10]. Secondly, previous studies suggest that the fraction of bacteria associated with particles decreases with particle size; Schillinger and Gannon [24] found $10 \%, 3 \%, 2 \%$, and $12 \%$ of the fecal coliforms where associated with particle fractions less than $52 \mu \mathrm{m}, 30$ $52 \mu \mathrm{m}, 10-30 \mu \mathrm{m}$, and $5-10 \mu \mathrm{m}$, respectively, with $80 \%$ being dispersed in solution $(<5 \mu \mathrm{m})$. These results suggestion the variations between modeled and observed survival in the tailing phase may be different for storm water and wastewater or the mechanism responsible for tailing may be fundamentally different than via the shielding commonly assumed. 


\section{Conclusions}

The initial rate of UV disinfection for E. coli was found to decrease with decreasing particle size. A biphasic model accurately described both the initial and tailing phase of bacterial survival. A particle-associated bacteria model based on previous work by Emerick et al. [16] and observed relationships between total suspended solids and particle number [21] was found to adequately describe tailing for unfractioned CSO samples. However, when smaller particle size fractions were investigated, the particle-associated bacteria model and presumably the shielding accounted for by this model did not accurately describe bacterial survival. While higher concentrations of suspended solids need to be investigated, the model developed within this paper appears to be sufficient to predict tailing observed during UV disinfection for unfiltered CSO water with low concentrations of suspended solids.

\section{Acknowledgement}

This work was supported by Detroit Contracting Inc. (project number CM 10110).

\section{References}

[1] Wolfe, R.L., et al., Disinfection of model indicator organisms in a drinking water pilot plant by using PEROXONE. Applied and Environmental Microbiology, 55(9): pp. 2230-2241, 1989.

[2] Loge, F.J., et al., Variations in wastewater quality parameters influencing UV disinfection performance: Relative impact of filtration. Journal of Environmental Engineering - ASCE, 127(9): pp. 832-837, 2001.

[3] Qualls, R.G. and J.D. Johnson, Bioassay and dose measurement in UV disinfection. Applied and Environmental Microbiology, 45(3): pp. 872$877,1983$.

[4] Cairns, W., et al., Assessing UV disinfection of a physicochemical effluent by medium pressure lamps using a collimated beam and pilot plant. In Planning, design \& operation of effluent disinfection systems. Whippany, NJ, 1993.

[5] Darby, J., et al., Comparison of UV irradiation to chlorination. guidance for achieving optimal UV performance. Water Environmental Research. Alexandria, Virginia, 1995.

[6] Masschelein, W., Ultraviolet light in water and wastewater sanitation. CRC Press LLC, Boca Raton, Florida, 2002.

[7] Mamane, H., Impact of particles on UV disinfection of water and waste water effluents: a review. Reviews in Chemical Engineering, 24(2-3): pp. $67-157,2008$. 
[8] Betancourt, W.Q. and J.B. Rose, Drinking water treatment processes for removal of Cryptosporidium and Giardia. Veterinary Parasitology, 126(12): pp. 219-234, 2004.

[9] Rompre, A., et al., Detection and enumeration of coliforms in drinking water: current methods and emerging approaches. Journal of Microbiological Methods, 49(1): pp. 31-54, 2002.

[10] Akerlund, T., K. Nordstrom, and R. Bernander, Analysis of cell size and DNA content of exponentially growing and stationary phase batch cultures of Escherichia coli. Journal of Bacteriology, 177(23): pp. 6791-6797, 1995.

[11] Madge, B.A. and J.N. Jensen, Ultraviolet disinfection of fecal coliform in municipal wastewater: Effects of particle size. Water Environment Research, 78(3): pp. 294-304, 2006.

[12] Wolfe, R.L. Ultraviolet disinfection of potable water - Current technology and research needs. Environmental Science \& Technology, 24(6): pp. 768-772, 1990.

[13] Bolton, J.R. and K.G. Linden, Standardization of methods for fluence (UV dose) determination in Bench-scale UV experiments. Journal of Environmental Engineering ASCE, 129 (3): pp. 209-215, 2003.

[14] Qualls, R.G., et al., Factors controlling sensitivity in ultraviolet disinfection of secondary effluents. Journal Water Pollution Control Federation, 57(10): pp. 1006-1011, 1985.

[15] Caron, E., et al., Impact of micro particles on UV disinfection of indigenous aerobic spores. Water Research, 41(19): pp. 4546-4556, 2007.

[16] Emerick, R.W., et al., Modeling the inactivation of particle-associated coli form bacteria. Water Environment Research, 72(4): pp. 432-438, 2000.

[17] Bissonnette, G.K., et al., Influence of environmental stress on enumeration of indicator bacteria from natural waters. Applied Microbiology, 29(2): pp. 186-194, 1975.

[18] Gates, F.L., A study of the bactericidal action of ultraviolet light. III. The absorption of ultraviolet light by bacteria. Journal of General Physiology, 14: p. 31-42, 1930.

[19] Standard Methods 9222. Standard total coli form membrane filter procedure., in Standard Methods for the Examination of Waste and Wastewater, L.S. Clesceri, A.E. Greenberg, and A.D. Eaton, Editors. American Public Health Association, American Water Works Association, Water Environment Federation: Washington, DC. pp. 5.31-5.34, 1998.

[20] Hellweger, F.L., et al., Biphasic decay kinetics of fecal bacteria in surface water not a density effect. Journal of Environmental Engineering. 135(5): pp. 372-376, 2009.

[21] Li, Y.X., et al., Dynamic characteristics of particle size distribution in highway runoff: Implications for settling tank design. Journal of Environmental Engineering - ASCE. 132(8): pp. 852-861, 2006.

[22] Mendenhall, W. and T. Sincich, Statistics for Engineering and the Sciences. San Francisco, CA: Dellen Publishing Co., 1992. 
[23] Guo, M.T., et al., Comparison of low-and medium-pressure ultraviolet lamps: Photo reactivation of Escherichia coli and total coliforms in secondary effluents of municipal wastewater treatment plants. Water Research, 43(3): pp. 815-821, 2009.

[24] Schillinger, J.E. and J.J. Gannon, Bacterial adsorption and suspended particles in urban storm water. Journal Water Pollution Control Federation, 57(5): pp. 384-389, 1985. 